\title{
POLA PEMBINAAN MORAL KEAGAMAAN NARAPIDANA MASA PANDEMI COVID 19
}

\author{
Mardiyah Hayati ${ }^{1}$, Alfiatun ${ }^{2}$ \\ 1Program Studi PGMI, Universitas Muhammadiyah Mataram, ${ }^{2}$ SMP Negeri 01 Kediri- Lombok Barat, Indonesia \\ Mardiyahhayati4@gmail.com¹ ${ }^{1}$ alfiatunhj@gmail.com²
}

\section{INFO ARTIKEL}

\section{Riwayat Artikel:}

Diterima: 02-03-2021

Disetujui: 30-04 -2021

\section{Kata Kunci: \\ Pembinaan Moral \\ Keagamaan \\ Narapidana, \\ Lembaga \\ Pemasyarakatan \\ Perempuan Mataram, Pandemi Covid 19.}

\section{Keywords \\ Convict Religious Moral \\ Development, \\ Mataram Women's \\ Correctional Institution, \\ Covid-19 pandemic}

\begin{abstract}
ABSTRAK
Abstrak: Sistem pemasyarakatan bertujuan untuk mengembalikan Warga binaan Pemasyarakatan di Lembaga Pemsyarakatan Perempuan Kelas III Mataram sebagai warga yang baik, sekaligus melindungi masyarakat terhadap kemungkinan berulangnya tindak pidana, sehingga diperlukan keikutsertaan masyarakat dalam program pembinaan dengan mengadakan kerjasama dalam proses pembinaan agama. Penelitian ini bertujuan untuk 1) mengetahui pola pembinaan moral keagamaan bagi narapidana dan tahanan di Lembaga Pemasyarakatan Perempuan Mataram, 2) Mengetahui implikasi pembinaan moral kegamaan Narapidana di masa pandemic Covid 19, 3) Mengetahui kendala pada proses pembinaan keagamaan pada narapidana masa Covid 19 di Lembaga Pemasyarakatan Perempuan Mataram. Metode pengumpulan data dilakukan dengan tiga metode yaitu 1) Wawancara, 2) Observasi dan 3) Dokumentasi. Hasil dari penelitian ini menemukan bahwa: 1. Pembinaan tidak bisa maksimal karena menggunakan sistem online. 2. Peserta warga binaan kurang fokus disebabkan seringnya gangguan jaringan 3 . Adanya perbedaan pendidikan para narapidana menjadi kendala dalam menjalankan materi dan silabus yang sudah di persiapkan sebelumnya

Abstract: The correctional system aims to return the prisoners in the Class III Mataram Women's Penitentiary as good citizens while protecting the community against the possibility of repeating criminal acts, so that community participation in the coaching program is needed by cooperating in the process of religious development. This study aims to 1) find out the pattern of religious moral development for prisoners and detainees at the Mataram Women's Correctional Institution, 2) find out the implications of religious moral development for prisoners during the Covid 19 pandemic, 3) find out the obstacles in the process of religious development for inmates during the Covid 19 period in the prison. Mataram Women's Correctional. Methods of data collection are done by three methods, namely 1) Interview, 2) Observation, and 3) Documentation. The results of this study found that: 1. Coaching cannot be maximized because it uses an online system. 2. The inmates lack focus due to frequent network disturbances 3. The difference in the education of the prisoners becomes an obstacle in carrying out the materials and syllabus that have been prepared previously.
\end{abstract}

\section{A. LATAR BELAKANG}

Hidup dan kehidupan adalah sebuah proses bagi setiap manusia untuk selalu bergerak.Hidup pada abad modern yang semakin canggih,bukan hal yang mudah bagi manusia. Mereka semakin dihadapkan pada persoalan diri sendiri maupun pada lingkungan pergaulan mereka. Keadaan masyarakat dan kondisi lingkungan dalam berbagai corak dan bentuknya akan berpengaruh, baik langsung maupun tidak langsung pada manusia itu sendiri.

Kondisi demikian disebabkan oleh karena adanya penurunan nilai-nilai sosial secara drastis, disamping adanya degradasi common interes masyarakat terhadap pelaksanaan nilai-nilai agama. Padahal moral tanpa agama tidak berfungsi.

Pergeseran nilai-nilai agama, akhlak, moralitas, nilai budaya yang berujung pada tindakan kriminalitas ini tentu dipengaruhi banyak faktor, diantaranya adalah kemajuan-kemajuan pada beberapa aspek kehidupan, yang memposisikan setiap anggota masyarakat untuk bersaing secara keras dan tidak mengindahkan tata aturan sosial secara fair. Pada dasarnya setiap masyarakat yang telah maju dan modern, berkepentingan untuk mengendalikan kejahatan dan menguranginya serendah mungkin.(Romli :2010:3) Salah satu solusinya adalah dengan pembinaan moral. Pembinaan adalah sesuatu yang sangat penting karena maju mundurnya suatubangsa terletak pada baik buruknya moral 
masyarakat tersebut. Masalah moral adalah suatu masalah yang menjadi perhatian orang dimana saja, baik dalam masyarakatyang telah maju, maupun dalam masyarakat yang masih terbelakang,(Zakiah :2020) yang selalu mewarnai kehidupan manusia dari masa ke masa. Persoalan moral menjadi salah satu dari berbagai kompleksitas persoalan kemanusiaan yang senantiasa harus dicermatisecara serius, sebab seiring dengan laju modernitas,kompleksitas persoalan manusiapun semakin bertambah. (Zainul, dkk: 2012)

Dalamprinsip-prinsip untuk pendidikan nilai, moral dankarakter, maka salah satu prinsipnya adalah prinsip disiplin diri (self discipline), yang terdiri dari nilai, moral dan karakter kebulatan tekad (determination), kepatuhan (obedience),dan pengendalian (restraint), "When we have the determination to restraint ourlower desires, the door is opened for us to fulfill our highest aspira-tions. Through obedience to our higher self, we develop an inner con-trol and greater confidence on ourselves ". (www.teachingvalues.com; July 9, 2008). Tekad seseorang untuk mengendalikanhasrat-hasrat yang lebih rendah, akan terbuka bagi pemenuhanaspirasi-aspirasinya yang tertinggi. Salah satunya adalah melaluinilai, moral dan karakter kepatuhan terhadap diri yang lebihtinggi, mengembangkan kontrol diri dan kepercayaan yang lebih besar terhadap diri sendiri. Untuk mengembangkan kontrol diridan kepercayaan, lebih dulu perlu dibentuk dan dibina nilai,moral dan karakter kepatuhan. (Sarbaini :2012: 9)

Dalam pandangan al-Qur'an semua sifat manusia dibagi dalam dua kategori yang secara radikal sangat bertentangan, mengingat kenyataan bahwa kategori-kategori tersebut sangat kongkrit dan secara semantik sungguh tepat untuk disebut dengan predikat baik dan buruk atau benar dan salah. Secara sederhana dapat dikatakan kelas yang memiliki sifat moral yang positif dan kelas yang memiliki sifat moral yang negatif.

Narapidana adalah orang yang pada suatu waktu tertentu menjalani pidana, karena dicabut kemerdekaan bergeraknya berdasarkan keputusan hakim. Narapidana adalah seorang terhukum yang dikenakan pidana dengan menghilangkan kemerdekaannya ditengah-tengah masyarakat yang telah mendapat putusan pengadilan (hakim). Tujuan dari hukuman ini adalah untuk menjerakan dan melindungi masyarakat terhadap kejahatan yang telah di lakukannya. Pelaksanaan hukuman itu berbentuk melakukan penutupan paksa dengan jalan diasingkan dari masyarakat kedalam lembaga pemasyarakatan/Rumah tahanan negara.
Narapidana juga adalah makhluk sosial,oleh karena itu haruslah di tanamkan kepada setiap narapidana bahwa ia adalah anggota masyarakat. Setiap anggota masyarakat harus menaati, mematuhi, menjalankan kaidah-kaidah yang berlaku di masyarakat. Maka didalam sistem pemasyarakatan dalam pembinaannya, narapidana tidak boleh diasingkan dari masyarakat ramai, melainkan perlu dipergaulkan ke tengah-tengah masyarakat umum (Mappanyompa \& Ali, 2017).

Salah satu cara yang ditempuh pemerintah untuk menanggulangi kriminalitas,yaitu dengan cara memberi pembinaan bagi para pelaku tindak kriminal/narapidana yang dilaksanakan disebuah lembaga tertentu yang di sebut Lembaga Pemasyarakatan. Pembinaan narapidana mempunyai arti memperlakukan seseorang yang berstatus narapidana untuk dibangun agar bangkit menjadi seseorang yang baik. Lembaga Pemasyarakatan menjadi lembaga yang dibebani peran untuk melayani kepentingan masyarakat terutama memberikan dampak penghukuman.

Salah satu lembaga pemasyarakatan yang berperan membina tahanan dan narapidana di wilayah Nusa Tenggara Barat adalah Lembaga Pemasyarakatan Perempuan kelas III kota Mataram.Sebagai kota yang sedang berkembang dan merupakan ibukota provinsi Nusa Tenggara Barat kota Mataram memiliki tingkat kriminalitas yang cukup tinggi. Oleh sebab itu Lembaga Pemasyarakatan ikut andil dalam memberikan pembinaan bagi narapidana.

Saat ini dunia sedang dihebohkan dengan adanya penyakit/wabah virus Covid 19 termasuk Indonesia adalah salah satu negara yang terjangkit virus tersebut.Virus ini sangat berbahaya apalagi penyebarannya sangat cepat. WHO merilis kurang lebih ada 100 negara terjangkit oleh virus ini.Di Indonesia kasus ini sudah puluhan ribu. Dengan adanya virus ini Kementrian Hukum dan HAM Republik Indonesia Direktorat Jendral Pemasyarakatan mengeluarkan Surat Edaran No : PAS-OT.02.02.17 Tentang Penanganan Covid 19 dan ditindaklanjuti oleh Kantor Kementrian Hukum dan HAM Provinsi Nusa Tenggara Barat No : W.21.PK.01.07.01-1014. Dengan adanya Surat Edaran tersebut maka pembinaan di Lembaga Pemasyarakatan Perempuan Mataram khususnya pembinaan moralkeagamaan merubah pola pembinaan. Awalnya pembinaan dilakukan dengan tatap muka,maka saat ini sebagian pembinaan dilakukan dengan pertemuan daring (dalam jaringan). Tentu ini sangat berpengaruh terhadap proses dan hasil pembinaan narapidana. Disatu sisi jumlah penghuni Lembaga Pemasyarakatan semakin hari semakin bertambah. 


\section{Dasar Pembinaan Moral Agama Islam Narapidana.}

Dasar pembinaan moral keagamaan Islam narapidana adalah acuan bagi para pelaksana dan pendukung pembinaan moral agama dimana pada dasarnya sama dengan dasar hukum pembinaan dan dakwah agama, sebab sesungguhnya tujuan pokok dari dakwah adalah membina mental dan moral seseorang ke arah yang sesuai dengan ajaran agama sebagaimana yang tercantum dalam al-Qur'an surat An Nahl (16): 125 :

"Serulah (manusia) kepada jalanTuhan-mu dengan hikmah dan pelajaran yang baik dan bantahlah mereka dengan cara yang baik. Sesungguhnya Tuhanmu Dialah yang lebih mengetahui tentang siapa yang tersesat dari jalanNya dan Dialah yang lebih mengetahui orang-orang yang mendapat petunjuk".

Dari ayat diatas jelas bahwa pembinaan moral agama adalah merupakan tanggungjawab setiap muslim berdasarkan kemampuannya masing-masing, dan pembinaan moral agama bagi narapidana juga merupakan bagian dari proses pembinaan.

\section{Tujuan Pembinaan Moral Agama Islam Narapidana}

Pembinaan sebagai sarana untuk memberi dan mendidik agar tercipta hasil binaan yang sesuai dengan yang ingin dicapai pembina sangatlah penting, terutama bila pembinaan itu menyangkut kompleksitas manusia yang memiliki beragam harapan dan cita-cita. Dalam Kitab Undang-Undang Hukum Pidana Tujuan pembinaan di lembaga pemasyarakatan dibagi kedalam 3 hal:

a. Setelah keluar dari lembaga pemasyarakatan tidak lagi melakukan tindakan pidana,

b. Menjadi manusia yang berguna, berperan aktif dan kreatif dalam membangun bangsa dan negaranya,

c. Mampu mendekatkan diri kepada Tuhan Yang Maha Esa dan mendapatkan kebahagiaan di dunia dan akhirat.

\section{Lembaga Pemasyarakatan Dalam Pembinaan Narapidana}

a. Pola Pembinaan Narapidana dalam Sistem Pemasyarakatan. Sistem Pemasyarakatan di negara kita dalam kenyataannya belum dapat sepenuhnya dikatakan sebagai suatu sistem pemasyarakatan yang sesungguhnya. Gunakarya berpendapat bahwa apabila kita membahas tentang sistem pemasyarakatan yang sesungguhnya harus memiliki beberapa unsur, yaitu: a. Harus adanya sarana peraturan perundang-undangan dan peraturan pelaksanaannya yang merupakan landasan struktural yang menunjang atau melaksanakan dasar bagi ketentuan operasional suatu konsepsi, dalam hal ini konsepsi pemasyarakatan; b. Harus tersedia sarana personil yang mencukupi dan memadai bagi kebutuhan pelaksanaan tugas pembinaan narapidana; c. Sarana administrasi keuangan, sebagai sarana materiil untuk kebutuhan operasional; d. Sarana fisik yang sesuai dengan kebutuhan bagi pelaksanaan pembinaan narapidana dalam proses pemasyarakatan.

b. b.Proses Pembinaan Narapidana dalam Sistem Pemasyarakatan.

Saat seorang narapidana menjalani vonis yang dijatuhkan oleh pengadilan, maka hak-hanya sebagai warga negara akan dibatasi. Sesuai Undang-Undang Nomer 12 Tahun 1995, Narapidana adalah terpidana yang menjalani pidana hilang kemerdekaannya di Lembaga Pemasyarakatan. Tetapi walaupun narapidana kehilangan kemerdekaannya, ada hak-hak narapidana yang dilindungi dalam Sistem Pemasyarakatan Indonesia.

Pembinaan adalah kegiatan yang bertujuan untuk menumbuhkan, mengembangkan, meningkatkan potensi yang ada dalam diri Warga Binaan Pemasyarakatan, maka selayaknya kegiatan tersebut dilakukan secara terus menerus dan terpadu.

Menurut Adi Sudjatno ruang lingkup pembinaan berdasarkan Keputusan Mentri Kehakiman Republik Indonesia Nomor: M.02PK.04.10 Tahun 1990 tentang Pola Pembinaan Narapidana dapat di bagi ke dalam 2 (dua) bidang yakni : (

1) Pembinaan Kepribadian yang meliputi antara lain:

a) Pembinaan kesadaran beragama

b) Pembinaan berbangsa dan bernegara

c) Pembinaan kemampuan intelektual (kecerdasan)

d) Pembinaan kesadaran hukum

e) Pembinaan mengintegrasikan diri dengan masyarakat

2) Pembinaan kemandirian diberikan melalui program-program:

a) Keterampilan untuk mendukung usaha mandiri, misalnya kerajinan tangan, industri rumah tangga, reparasi mesin dan alat-alat elektronika dan sebagainya.

b) Ketrampilan untuk mendukung usaha industri kecil, misalnya pengelolaan bahan mentah dari sektor pertanian dan bahan 
alam menjadi bahan setengah jadi dan menjadi bahan jadi

c) Keterampilan yang dikembangkan sesuai dengan bakat narapidana masing-masing

d) Ketrampilan untuk mendukung usaha-usaha industri atau kegiatan pertanian/ perkebunan dengan menggunakan teknologi madya atau teknologi tinggi, misalnya industri kulit, pabrik tekstil dan sebagainya.

Selain dari pada Pola Pembinaan Narapidana berdasarkan Keputusan Menteri Kehakiman Republik Indonesia Nomor: M.02PK.04.10 Tahun 1990 tentang Pola Pembinaan Narapidana/Tahanan, maka menurut Adi Sujatno ada unsur-unsur pokok dalam menunjang tujuan pembinaan dalam sistem pemasyarakatan, antara lain:

1) Narapidana itu sendiri

2) Para petugas/ pegawai lembaga pemasyarakatan

3) Masyarakat, dalam hal ini yang meliputi instansi-instansi swasta, organisasi sosial kemasyarakatan, keluarga dari narapidana itu sendiri.

\section{Moralitas}

Moral merupakan pengetahuan yang menyangkut budi pekerti manusia yang beradab. Moral juga berarti ajaran yang baik dan buruk, perbuatan dan kelakuan. Moralisasi berarti, uraian (pandangan, ajaran) tentang perbuatan kelakuan yang baik. Demoralisasi, berarti kerusakan moral. Moral berasal dari bahasa Latin mos, bentuk jamaknya mores yang berarti adat atau cara hidup. Moral dan moralitas di pakai untuk perbuatan yang sedang dinilai. Moralitas menunjukkan pada suatu konsep yang keseluruhannya memaknai suatu perbuatan dan berkaitan dengan hakekat nilai. Moralitas sangat terkait dengan eksistensi manusia seutuhnya. Driyarkara Norma moral adalah tolok ukur yang dipakai sebagai dasar oleh masyarakat untuk mengukur sampai sejauh mana kebaikan seseorang itu dalam rangka interaksi sosialnya. Dengan norma moral manusia dinilai. Walaupun moralitas dihubungkan dengan sikap dan perilaku individu, namun individu hanya bisa bersikap dalam konteks masyarakat yang memiliki budaya, struktur sosial, politik dan ekonomi tertentu. Moralitas publik yang dilatar belakangi oleh moralitas individual akan menghasilkan suatu kepatutan untuk kepentingan bersama jika kebijakan moralitas mengutamakan kepentingan publik dan bukan semata-mata kepentingan pribadi tertentu maupun golongan.

Mencermati pengertian moral di atas, nampak bahwa moral selalu berhubungan dengan nilai-nilai. Ada bermacam-macam nilai, seperti nilai logis (benar-salah), nilai estetis (indah-jelek), ataupun nilai moral (baik-buruk). Norma moral adalah tolok ukur yang dipakai untuk mengukur kebaikan seseorang. Dengan norma moral kita akan dinilai. Nilai moral tidak dapat terpisah secara tegas dengan perspektif nilai pada umumnya. Setiap nilai dapat memperoleh bobot moral jika diikutsertakan dalam tingkah laku moral. Kejujuran, misalnya merupakan suatu nilai moral, namun kejujuran itu sendiri seolah tidak bermakna secara hakiki, jika tidak dikaitkan dengan sistem nilai dasar lainnya misalnya nilai ekonomis. Kesetiaan merupakan contoh nilai moral, namun kesetiaan baru akan memiliki makna jika dikaitkan dengan nilai luhur cinta kasih dan hubungan suami istri.

Salah satu hal yang dapat memberikan nilai-nilai positif pada penghuni Lembaga Pemasyarakatan adalah dengan memberikan pembekalan agama. (Irma :2017). Nilai positif yang dimaksud tentu saja nilai moral.

Agama tidak dapat dipisahkan dengan moral, demikian juga sebaliknya. Seseorang tidak mungkin dapat sungguh-sungguh hidup bermoral tanpa agama. Bukti bahwa moralitas itu berkaitan erat dengan agama di landasi dengan sejumlah alasan yaitu :

a. Moralitas pada hakekatnya bersangkut paut dengan bagaimana manusia menjadi baik. Jalan terbaik pencapaian kebahagiaan sejati adalah melaksanakan perintah dan kehendak Tuhan. Perintah dan kehendak Tuhan itu hanya bisa diketahui melalui agama. Karenanya, moralitas akan hidup baik bagi manusia yang senantiasa mengandalkan agama.

b. Agama merupakan salah satu pranata kehidupan manusia yang paling lama bertahan sejak dahulu kala. Alasan ini semakin memperkuat bukti bahwa moralitas dalam masyarakat erat terjalin dengan praktek hidup beragama.

c. Agama menjadi penjamin yang kuat bagi hidup manusia bermoral.

Bagi seseorang yang di jatuhi hukuman pidana dan harus berada di lingkungan Lembaga Pemasyarakatan membutuhkan proses penyesuaian diri yang cukup berat. Salah satu yang menunjukkan peran positif dalam penyesuaian diri narapidana adalah agama.

\section{Pandemi Covid 19}

Pandemi Coronavirus 19 sangat banyak mempengaruhi berbagai kegiatan keagamaan di dunia. Pengaruh pandemic ini terhadap kehidupan keagamaan termasuk pembatasan kegiatan ibadah 
di masjid juga pembatasan perayaan hari besar agama. Hal ini dalam rangka mencegah berkumpulnya banyak orang selama masa pandemi. Kementrian agama Republik Indonesia menyerukan sholat Jum'at ditiadakan. Ummat Islam diserukan untuk melaksanakan sholat di rumah dan menghindari datang ke masjid untik sholat berjama'ah. Kegiatan rutin masyarakat Indonesia menjelang Iedhul Fitri yaitu mudik juga ditiadakan di tahun 2021 ini. Dengan merebaknya virus corona aktivitas masyarakat banyak berkurang tidak seperti biasanya bahkan ada sebagian daerah menerapkan lockdown sampai waktu yang ditentukan dan masyarakat tidak bisa menolak untuk beraktivitas dirumah.

Demikian juga dengan kegiatan di Lembaga Pemasyarakatan. Melalui Surat edaran dari Kementrian Hukum dan Hak Azasi Manusia Dirjen Pemasyarakatan tentang Penanganan Covid 19 dan ditindaklanjuti oleh Kantor Kementrian Hukum dan HAM Provinsi Nusa Tenggara Barat, maka pembinaan di Lembaga Pemasyarakatan Perempuan Kelas III Mataram juga mengalami banyak penyesuaian. Sebagian program Bimbingan agama dilakukan secara virtual.Untuk kondisi tertentu juga dilakukan tatap mukaHal ini tentu membuat para pembimbing harus mengalihkan strategi bimbingan yang semula dilakukan tatap muka secara penuh maka sekarang harus menggunakan media sosial yang menjadi alat penting dalam membantu aktivitas dakwah dan bimbingan bagi narapidana.

\section{B. METODE PENELITIAN}

\section{Teknik Pengumpulan Data}

Metode pengumpulan data yang di gunakan dalam penelitian ini adalah : observasi, wawancara dan dokumentasi.

a. Metode observasi atau pengamatan di lakukan pada waktu tindakan sedang berlangsung.(Sugiyono :2012:85) Observasi pertama kali dilakukan secara menyeluruh terhadap phenomena yang akan diteliti dengan melakukan penelitian melalui kajian pustaka dan fenomena lapangan yang akan di teliti guna memperoleh fokus penelitian dan mempelajari masalah penelitian. Dengan demikian obsevasi adalah pengamatan atau penyelidikan yang digunakan dengan menggunakan alat indera,baik langsung maupun tidak langsung terhadap fakta-fakta atau gejala-gejala yang akan diteliti. Tehnik obsevasi digunakan untuk membuktikan kebenaran data atau informasi yang diperoleh melalui wawancara. Dalam observasi akan diamati adalah proses bimbingan agama Islam di lembaga
Pemasyarakatan Perempuan pada masa Pandemi Covid 19.Peneliti akan mengamati secara langsung dan natural tanpa rekayasa yang terjadi selama observasi berlangsung. Untuk memperoleh data yang cermat peneliti akan berupaya untuk memasuki kondisi obyek.

b. Metode wawancara. Menurut Esterberg (dalam Sugiyono, 2016:232) wawancara merupakan pertemuan dua orang untuk bertukar informasi dan ide melalui tanya jawab sehingga dapat dikonstruksikan makna dalam suatu topik tertentu. Dalam penelitian ini, wawancara yang digunakan adalah wawancara semi terstruktur. Wawancara semi terstruktur bertujuan untuk menemukan permasalahan secara lebih terbuka, dimana narasumber diminta pendapat dan idenya. Metode ini digunakan untuk memperoleh informasi yang bersumber dari kepala LPP,petugas/pegawai,penyuluh agama/pembimbing agama dan warga binaan pemasyarakatan.

c. Metode dokumentasi adalah dokumen berupa catatan peristiwa yang sudah berlalu dan tersaji dalam bentuk tulisan, gambar, atau karya-karya monumental dari seseorang. Dokumen membuat hasil dari wawancara atau observasi akan lebih dipercaya atau kredibel. (Sugiyono, 2016:240). Dari definisi tersebut diketahui bahwa tehnik dokumentasi adalah suatu tehnik penelitian yang ditujukan kepada penguraian dan penjelasan terhadap apa yang tengah berlangsung melalui sumber-sumber dokumen dalam menggali suatu data. Dalam hal ini adalah dokumentasi tentang materi,strategi dan pola Bimbingan moral Keagamaan di Lembaga Perempuan Mataram.

\section{Analisis Data}

Beberapa langkah yang dapat dilakukan dalam menganalisis data antara lain : Langkah pertama adalah mereduksi data. Reduksi dilakukan dengan mengumpulkan data dari hasil wawancara,obsevasi dan dokumentasi serta data lapangan,kemudian dipilih dan dikelompokkan berdasarkan kemiripan data. Hasilnya kemudian akan diolah,diklasfikasi,dianalisis dan disimpulkan.

Langkah kedua yaitu penyajian data. Dalam hal ini data yang telah dikatagorikan tersebut kemudian diorganisasikan sebagai bahan penyajian data. Data tersebut disajikan secara deskriptif yang didasarkan pada aspek yang diteliti sehingga dimungkinkan dapat memberikan gambaran seluruhnya atau sebagian dari aspek yang akan diteliti.

Langkah ketiga verifikasi dan menyimpulkan,dalam hal ini peneliti akan 
menyeleksi kembali, mengklasifikasi dan menganalisi data kemudian menyimpulkan kembali. Tehnik pengambilan kesimpulan yang dipakai adalah metode deduksi dan induksi.Setelah itu data dianggap selesai dan dijadikan sebagai data akhir yang dijadikan sebagai bahan laporan penelitian. (Sugiyono : 2014: 402)

\section{HASIL DAN PEMBAHASAN}

Di Lembaga Pemasyarakatan Perempuan kelas IIIMataram menerapkan pola pembinaan narapidana berdasarkan peraturan perundanganundangan yang berlaku. Pembinaan keagamaan diberikan kepada warga binaan pemasyarakatan berdasarkan agama yang dianut oleh warga binaan pemasyarakatan. Bagi warga binaan pemasyarakatan yang beragama Islam diberikan pembinaan rohani diantaranya pembinaan sholat, baca tulis al-Qur'an, ceramah-ceramah agama melalui pengajian, kegiatan intensif di bulan Ramadhan dan lain-lain. Kegiatan tersebut bergiliran sesuai dengan jadwal yang telah ditentukan. (Dewi Andriani : 27 April 2021). Hal yang sama juga diberikan kepada narapidana yang beragama lain misalnya untuk yang beragama Hindu diberikan kegiatan belajar Weda. Khusus untuk narapidana di Lembaga Pemasyarakatan Perempuan Mataram, pembinaan dilakukan secara berkesinambungan, pembinaan kepribadian misalnya dengan melakukan sholat berjama'ah, olahraga yoga, bulutangkis, volleyball. Pelaksanaan pembinaan kemandirian diantaranya ketrampilan membuat bunga, menjahit, menyulam, serta berbagai pekerjaan rumah tangga seperti kebersihan halaman, kebersihan kantor, dan petugas dapur dilingkungan intern LPP. (L.Syamsul: 27 April 2021)

Dalam penyampaian materi pembinaan moral agama yang diberikan kepada warga binaan pemasyarakatan wanita Lembaga pemasyarakatan Perempuan Kelas III Mataram bekerjasama dengan lembaga Majelis Tabligh PW 'Aisyiyah NTB, dalam hal ini yang datang secara rutin untuk membina adalah ustadzah Dra.Hj.Alfiatun dan Mardiyah Hayati M.Pd.I.

Salah seorang ustadzah menjelaskan bahwa pendidikan dan ceramah-ceramah agama sangat perlu dilakukan secara terus-menerus agar warga binaan dapat menyadari kesalahan dan kekeliruan yang telah diperbuatnya sehingga dengan pemberian materi yang berkesinambungan mereka memahami norma moral dan norma agama yang perlu dipatuhi. (Hj. Alfiatun : 23 Maret 2021)

Pada masa pandemic Covid sekarang ini,Kementrian Hukum dan HM menerbitkan surat edaran No : W.21.PK.01.07.01-1014 tentang Penanganan Covid. Melalui surat edaran tersebut maka pembinaan di Lembaga Pemasyarakatan Perempuan Mataram khususnya pembinaan moral agama Islam merubah pola pembinaan. Awalnya pembinaan dilakukan dengan tatap muka,maka saat ini sebagian besar pembinaan dilakukan dengan daring (dalam jaringan). Namun pada kenyataannya pertemuan tatap muka juga sering dilakukan karena berbagai sebab.Adapun pembinaan moral keagamaan bagi tahanan dan narapidana yang dilaksanakan di LPP Kelas III Mataram diberikan berdasarkan pada agama yang dianut oleh warga binaan pemasyarakatan, khususnya bagi yang beragama Islam meliputi :

\section{Pengajian Rutin.}

Kegiatan ini wajib diikuti oleh semua narapidana dan tahanan yang beragama Islam. Dilaksanakan minimal 1 kali dalam 1 pekan dengan bekerjasama dengan Majelis Tabligh Pimpinan Wilayah 'Aisyiyah NTB dengan sukarela. Materi yang diberikan pada pengajian ini adalah: tauhid, akhlaq, fiqih, baca tulis al-Qur'an, dan Sejarah/ Tarikh Islam dan lain-lain. Tujuannya adalah untuk membekali tahanan dan narapidana dalam belajar dan mendalami ajaran Islam.

Berikut adalah data keaktifan warga binaan pemasyarakatan wanita di Blok Melati dalam mengikuti pengajian rutin :

Tabel 1

Pelaksanaan Pengajian rutin

\begin{tabular}{|l|l|l|l|}
\hline No & Pengajian rutin & Frekwensi & Prosentase \\
\hline 1. & Mengikuti & 100 & $95 \%$ \\
\hline 2. & Kadang-kadang & 7 & $7 \%$ \\
\hline 3. & Tidak mengikuti & - & - \\
\hline \multicolumn{2}{|c|}{ Jumlah warga binaan } & 107 orang & $100 \%$ \\
\hline
\end{tabular}

Bila melihat tabel diatas, maka dapat diketahui bahwa warga binaan pemasyarakatan wanita yang selalu mengikuti kegiatan ini ada 104 orang, yang kadang-kadang mengikuti 7 orang, sedangkan yang tidak pernah mengikuti tidak ada. Sebagaimana yang dikemukakan informan $\mathrm{X}$ yang mengemukakan manfaat mengikuti pengajian dan kegiatan-kegiatan keagamaan lainnya bahwa dengan aktif mengikuti kegiatan pembinaan melalui pembinaan agama membuatnya mengalami peningkatan dalam pemahaman dan pengetahuan mengenai berbagai aspek yang terdapat dalam ajaran agama Islam seperti fiqh, sejarah Islam dan lain-lain sehingga mengetahui mana yang benar dan mana yang salah. Namun karena pembinaan banyak dilakukan secara virtual 
maka materi tidak bisa maksimal mendengarkan.Pembinaan moral keagamaan membuatnya menjadi seorang individu yang lebih baik.

“Alhamdulillah karena ada ustadzah yang memberikan pelajaran agama melalui pengajian, saya jadi tau Insya Allah saya coba amalkan. Saya ingin keluarga bangga kalau ngeliat saya keluar dari sini nanti saya udah ngerti agama. Saya senang mendengarkan pengajian ustadzah karena suaranya lembut sekali, kadang juga tinggi suaranya tergantung materinya jadi saya senang, apalagi kalau pembahasannya tentang cara bertaubat, saya senang sekali."(Y:31 maret 2021)

Informan $\mathrm{Z}$ menyatakan bahwa pembinaan agama Islam yang didapatnya di masa pandemi ini dirasakan kurang puas karena hanya mendengarkan pengajian ustadzah melalui virtual, namun itu bisa tertutupi dengan adanya utadzah yang datang setiap malam ketika bulan Ramadhan. Namuntetap saja tidak puas.

Pelajaran akhlak yang didapatnya menjadikannya mengetahui beberapa hal, seperti apa yang harus diperbuatnya dalam hidup, menjaga lisan dalam mengeluarkan kata-kata, mana yang benar mana yang salah, apa yang harus diketahui dan siapa yang harus dikenal menurut ajaran Islam. Hal tersebut seperti yang diungkapkannya berikut ini :

Metode yang digunakan dalam kegiatan pengajian rutin antara lain : (Hj.Alfiatun: 3 Maret 2021)

a. Metode ceramah; metode ini digunakan para pembinadalam menyampaikan materi.

b. Metode tanya jawab atau dialog: Apabila warga binaan pemasyarakatan menghadapi suatu permasalahan atau kurang paham terhadap materi yang disampaikan, dapat ditanyakan langsung kepada pembina, sehingga tidak terjadi kesalahpahaman atau ketidakjelasan dalam penerimaan materi.

c. Materi praktek : materi ini tujuannya adalah untuk memperjelas materi yang disampaikan contohnya materi tentang sholat, wudhu, mandi besar, tayammum dan lain-lain. Ustadzah langsung mempraktekannya dan sering di putar video sholat.

d. Menterjemahkan ayat dan menggali hikmah dari ayat-ayat al-Qur'an.

\section{Baca Tulis al-Qur'an/Tila>wah ayat.}

Materi ini diberikan dengan tujuan agar warga binaan pemasyarakatan wanita memahami manfaat membaca al-Qur'an. Al-Qur'an adalah kitab suci sekaligus sebagai pedoman hidup umat Islam di dunia untuk menuju hidup yang lebih langgeng di akherat kelak serta sebagai petunjuk dan pembeda antara yang benar dan yang salah. Disamping itu membaca al-Qur'an merupakan ibadah dan mendapatkan pahala yang besar.

Pelaksanaannya setiap hari terutama pada saat penelitian ini dilakukan bersamaan dengan bulan Ramadhan. Untuk siang hari dibimbing oleh petugas LPP dan malam hari oleh ustadhah Dra.Alfiatun dan Ustadzah Mardiyah Hayati sesudah sholat tarawih.

\section{Sholat Berjama'ah}

Mendirikan shalat merupakan rukun Islam yang kedua. Mendirikan shalat secara kontinyu sesuai dengan waktu-waktu yang telah ditetapkan dengan memenuhi syarat dan rukunnya.

Kedisiplinan shalat adalah salah satu aspek pembinaan yang positif, yang dapat menjadikan manusia hidup teratur dalam lingkungan masyarakat. Dengan kewajiban shalat yang diajarkan oleh ustadzah bersama pembina pemasyarakatan sebanyak lima kali sehari semalam, terdiri dari tujuhbelas raka'at, dapat melatih kedisiplinan warga binaan pemasyarakatan untuk melaksanakan shalat tepat pada waktunya, sekaligus sebagai perantara untuk mendekatkan diri kepada Allah SWT.

\section{Tabel 2}

Pelaksanaan Shalat Lima waktu (Observasi 24 April 2021)

\begin{tabular}{|l|l|l|l|}
\hline No & Sholat 5 waktu & Frekwensi & Prosentase \\
\hline 1. & Selalu melaksanakan & 85 & $76,9 \%$ \\
\hline 2. & Melaksanakan & 5 & $5 \%$ \\
\hline 3. & Kadang-kadang & 17 & $10 \%$ \\
\hline \multicolumn{2}{|c|}{ Jumlah } & 107 Orang & $100 \%$ \\
\hline
\end{tabular}

Dalam pelaksanaan shalat, warga binaan pemasyarakatan sangat dianjurkan melakukannya berjama'ah, karena pahala shalat berjama'ah lebih banyak daripada shalat sendiri. Selain itu juga dapat menumbuhkan kebersamaan antar warga binaan pemasyarakatan.

\section{Kegiatan Bulan Ramadhan.}

Pada bulan suci Ramadhan, seluruh umat Islam di dunia diwajibkan berpuasa. Pada bulan inilah waktu yang tepat untuk semakin memperbanyak amal kebajikan ketika di dunia. Disamping berpuasa dibulan Ramadhan juga dilaksanakan shalat taraweh dengan imam bergantian ustadzah dari Majelis Tabligh PW 'Aisyiyah NTB sekaligus diisi dengan kultum dan tadarrus al-Qur'an yang dilaksanakan setelah shalat taraweh. 
5. Peringatan hari-hari besar Agama Islam, dilaksanakan dengan memberi ceramah dan pengajian umum dengan menitikberatkan pada tema yang menyangkut hari besar tersebut kemudian diselingi dengan tanya jawab dan diskusi seputar hal tersebut.

6. Memperbanyak buku-buku tentang ajaran agama Islam.

a. Implikasi Pembinaan Moral Agama Terhadap Perubahan perilaku Narapidana di LPP Kelas III Mataram.

Menurut pembina/penyuluh agama yang telah membina moral agama bagi tahanan dan narapidana perempuan melalui pendidikan dan pengajian di LPP bahwa proses pembinaan selama ini telah berjalan secara rutin dan baik sehingga memberikan pengaruh yang positif baik untuk narapidana itu sendiri maupun untuk lingkungannya. Selama ini tidak pernah terjadi keributan besar dan gejolak antar warga binaan. Hal tersebut sebagaimana dikemukakan oleh ustadzah berikut ini:

"Implikasi pembinaan agama yang kami rasakan selama ini antara lain adalah: 1) bagi petugas lembaga pemasyarakatan: disamping dapat belajar bersama-sama dengan narapidana, kami berpikir bahwa pembinaan agama membuat warga menjadi sangat tenang sehingga kami tidak terlalu capek mengatasi keributan antar napi, jadi kami dapat bertugas dengan tenang. 2) bagi narapidana sendiri, pembinaan melalui pengajian dan pembinaan moral agama mendapat dorongan moril bahwa Allah pasti mau menerima taubat dari kesalahan yang pernah dibuatnya, sehingga hati menjadi tenang, yang tadinya tidak bisa baca AlQur'an menjadi bisa, yang tadinya malas shalat sekarang jadi mau shalat, bahkan shalat sunnahpun menjadi kebutuhan."(Hj.Alfiatun : 3Maret 2021)

Petugas di LPP Kelas III Kota Mataram juga merasakan manfaat dari penyampaian materi yang secara rutin di berikan, berikut penuturan $\mathrm{mb}$ Arum, salah seorang petugas LP Kelas III A Mataram :

"Saya juga senang jika dapat giliran tugas jaga pada saat waktunya pembinaan agama sebab dapat ikut belajar bersama napi wanita, karena terus terang ilmu agama saya juga rendah, begitu juga dengan mengaji saya rasa sayapun mesti belajar lagi." (Arum: 24 maret 2021) Pelaksanaan pembinaan moral agama bagi narapidana wanita di Blok Melati LP kelas II A Kota Mataram juga berimplikasi pada perubahan mental dan perilaku selama mereka berada di lembaga pemasyarakatan yaitu ketika warga binaan pemasyarakatan merasa hidup mereka lebih bermakna.
Kendala Pelaksanaan Pembinaan Moral Keagamaan di Lembaga Pemasyarakatan Perempuan kelas III Mataram di Masa Covod 19.

1. Adanya perbedaan pendidikan warga binaan pemasyarakatan.

Salah satu kendala dalam penyampaian materi dalam proses pembelajaran terhadap warga binaan pemasyarakatan wanita adalah beragamnya latar belakang pendidikan. Penggunaan metode ceramah menjadikan para ustadzah kesulitan memberi pemahaman karena beragamnya tingkat pendidikan, latar belakang sosiokultural, sehingga kemampuan warga dalam memahami materi pelajaran yang diberikan juga berbeda. Penyampaian materi pelajaran bisa jadi terlalu tinggi atau rendah menurut kapasitas warga binaan sehingga berdampak pada keberhasilan program pembinaan.

2. Bimbingan Agama Islam dengan materi ibadah di tengah wabah Covid 19 memiliki beberapa kendala :

a. Praktek ibadah tidak maksimal karena visualisasi melalui media zoom sangat terbatas karena pembimbing kesulitan memberikan praktek secara langsung saat menyampaikan materi.

b. Sebagian peserta sering tidak fokus mengikuti bimbingan karena disaat sedang bimbingan jaringan tiba tiba terjadi gangguan demikian juga dengan pembimbing. Yang semula sudah bersiap memberikan dan mempraktekkan materi terjadi gangguan jaringan sehingga kehilangan konsentrasi ketika sedang berceramah.

c. Beberapa kali pembimbing tidak jadi memberikan bimbingan karena terjadi kasus tertentu,misalnya adanya percobaan bunuh diri oleh salah seorang tahanan ketika proses bimbingan sedang berjalan sehingga proses menjadi terhenti namun kemudian diadakan pertemuan dan bimbingan khusus kepada narapidana tersebut.

\section{SIMPULAN}

Berdasarkan paparan data diatas,hasil penelitian dan pembahasan pada bab sebelumnya maka simpulan dari penelitian ini adalah

Pembinaan moral Keagamaan di Lembaga Pemasyarakatan Kelas III Mataram sudah sesuai dengan Keputusan Mentri Kehakiman Republik Indonesia Nomor : M.02-PK 04.10 Tahun 1990 tentang Pola Pembinaan Narapidana yaitu pembinaan kesadaran beragama dengn melakukan pengajian rutin keagamaan, baca tulis/tilawah alQur'an, pembinaan shalat berjamaah, intensitas pembinaan di bulan ramadhan, memperbanyak 
buku-buku bacaan yang ada kaitannya dengan agama. Metode yang dipergunakan dalam penyampaian materi adalah metode ceramah, tanya jawab/ metode praktek, dengan materi penumbuhkembangan moral pribadi narapidana

Program pembinaan agama selama ini dianggap cukup berhasil menurunkan tingkat resedivisme karena hanya sedikit resedivis yang kembali terkena kasus. Hal itu menunjukkan bahwa tingkat efektivitas pelaksanaan program yang cukup tinggi dalam menekan jumlah residivis. Menurut ustadzah, ada 2 dampak pembinaan moral agama : pertama : Bagi petugas lembaga pemasyarakatan diantaranya adalah mengurangi residivisme. Dampak lainnya adalah munculnya semangat dari beberapa petugas wanita untuk sama-sama belajar dalam pengajian bersama dengan warga binaan. Kedua : bagi narapidana : dengaan adanya pembinaan moral agama maka ada yang memandu mereka dalam mendekatkan diri kepada Allah, hati menjadi lebih tenang, yang tadinya tidak bisa mengaji menjadi bisa. Yang tadinya malas shalat menjadi rajin shalat, bahkan shalat sunnahpun menjadi kebutuhan.

Hambatan/kendala dalam proses pembinaan moral agama di masa pandemic Covid 19:

a. Praktek ibadah tidak maksimal karena visualisasi melalui media zoom sangat terbatas karena pembimbing kesulitan memberikan praktek secara langsung saat menyampaikan materi.

b. Sebagian peserta sering tidak fokus mengikuti bimbingan karena disaat sedang bimbingan jaringan tiba tiba terjadi gangguan demikian juga dengan pembimbing. Yang semula sudah bersiap memberikan dan mempraktekkan materi terjadi gangguan jaringan sehingga kehilangan konsentrasi ketika sedang berceramah.

c. Beberapa kali pembimbing tidak jadi memberikan bimbingan karena terjadi kasus tertentu,misalnya adanya percobaan bunuh diri oleh salah seorang tahanan ketika proses bimbingan sedang berjalan sehingga proses menjadi terhenti namun kemudian diadakan pertemuan dan bimbingan khusus kepada narapidana tersebut.

\section{DAFTAR RUJUKAN}

Arifin, Zainul, dkk. Al Qur'an dan Tantangan Modernitas. Yogyakarta: Gama Media, 2012.

Darajat, Zakiyah. Islam dan Kesehatan Mental, 2020.

Faqih Ainur Rohim. Bimbingan dan Konseling Dalam Islam, Yogyakarta, UII Press, 2011.

Irma Silawaty dan Mochamad Ramdan. Peran
Agama Terhadap Penyesuaian Diri Narapidana di Lembaga Pemasyarakatan, Jurnal Psikologi Sosial Fakultas Psikologi UI, Vol 3 No 13, Agustus 2017.

Mubarok. Metodologi Dakwah Terhadap Narapidana. Jakarta: ProyekPenerangan Bimbingan dan Dakwah DEPAG Media, 2018.

Nata, Abuddin.Akhlak Tasawuf. Jakarta: Rajawali Press, 2013.

Priyanto, Dwija. Sistem Pelaksanaan Pidana Penjara di Indonesia.Bandung: Refika Aditama, 2016.

Romli Atmasasmita.Teori dan Kapita Selekta Kriminalitas.Bandung: 2010.

Sarbaini (2012) Pembinaan Nilai Moral dan karakter Kepatuhan Peserta Didik Terhadap Norma Ketertiban di sekolah (Landasan Konseptual, Teori, Juridis, dan Empiris), Yogyakarta; Aswaja Pressindo

Soedjatno, Adi. Sistem Pemasyarakatan IndonesiaMembangun Manusia Madani, Jakarta: Dirjen Pemasyarakatan Hukum dan HAM RI, 2014.

Sugiono. Metode Penelitian Kuantitatif Kualitatif dan R\&D. Bandung: Alfabeta, 2012.

Sugiyono. (2014). Metode Penelitian Pendidikan PendekatanKuantitatif, Kualitatif, dan R\&D. Bandung: Alfabeta.

Mappanyompa, A. M. (2017). Urgensi Penggunaan Multimedia Interaktif Terhadap Peningkatan Motivasi Belajar Siswa Dalam Pembelajaran Bahasa Arab. 2(2), 54-80. https://scholar.google.com /citations?user=svq93hwAAAAJ\&hl=en \& authuser $=1$

Sugiyono. (2016). Metode Penelitian Kuantitatif, Kualitatif dan R\&D. Bandung: PT Alfabet.

Surajiyo. Manusia Susila di Indonesia dalam Perpektif Filosofis, Jurnal Humaniora UGM, Vol XII, no 2,2012.

Ulwan, Abdullah Nashih. 2015. Tarbiyat al Aulad fi al Islam,Mesir,Dar el Salam (terjemah: Pendidikan Anak dalam Islam)., Jawa Tengah: Al-Andalus.

Widiyanti Ninik dan Yulius Waskita. Kejahatan Dalam Masyarakat dan Pencegahannya. Jakarta: Bina Aksara,2017.

Wiranata, I Gede AB. Dasar-Dasar Etika dan Moralitas Pengantar Kajian Etika Profesi Hukum, Bandung : Mandar Maju, 2011. 